\title{
The Public Intellectual ${ }^{1}$
}

\section{Craig Heron, York University}

Each year the Canadian Association of University Teachers bestows an award on a "distinguished scholar" who has demonstrated breadth of accomplishment in teaching, research, and service. All the recipients have had heavy involvement in the broader community, and fall into that loose category that we like to call the "public intellectual." So I thought it would be appropriate to reflect on what goes into making such a creature and to reflect on my own experience in somehow or other becoming one.

I cannot say that I remember ever setting out to be a public intellectual. I do not recall coming down to breakfast one morning and telling my parents that that was what I wanted to be when I grew up. But in a modest way I became one. As a graduate student and then as a full-time faculty member, I made links between my life inside the academy and my engagements outside. There were others like me who were entering academic training and employment in the 1970s, but we were far from typical, far from a majority.

I should begin by trying to unpack the term "public intellectual." We can start by asking: who or what is an intellectual? Although others may give us the label, it is certainly not a recognized occupational category - we do not tell censustakers that we work as intellectuals. Loosely, I think there is general agreement with the Oxford English Dictionary that an intellectual is "a person who cultivates the mind or mental powers and pursues learning and cultural interests," but that definition does not actually take us very far because there are so many different ways to "cultivate the mind," and there are so many different contexts across time for doing so. I will spare you a lengthy ride through the sociology of knowledge and the social-structural place of intellectuals. But looking across the twentieth and early twenty-first centuries, I think we can find intellectuals in several distinct niches. There are those operating primarily in the world of journalism, those rooted in religious or cultural institutions, those attached to various social and political movements, and of course, those who work in post-secondary institutions. I want to focus here on the intellectuals who have held full-time positions in universities and have reached beyond the ivory tower to a wider public.

The public intellectual has long had an uncertain status in the modern university. For generations, the norm for Canadian academics was to focus inward on education for their students and on scholarship to be shared and assessed by their peers within the academic world. This was the pursuit of pure knowledge, whose indirect benefit to society would be manifest in the fullness of time. In practice, of course, there were many newer parts of the university that had no such narrowly 
monkish orientation. These were the professional faculties of law, medicine, engineering, and so on, which had to meet the expectations of external accreditation agencies and markets for their skills, and the emerging business programs, which had a more open face to the world of commerce and industry. But for the liberal arts and much of the natural sciences, deeply rooted conventions looked askance at too much engagement beyond the ivy-covered walls. Speaking out publicly was supposed to be a distraction from the pursuit of truth. Some academics undoubtedly did, but anyone interested in establishing a more public voice had to make sure that it did not in any way threaten their academic careers, or the reputations of the institutions that hired them. There were some well-publicized cases of academics who stepped over the line. In 1941, for example, the University of Toronto historian Frank Underhill faced a serious threat of being fired for publicly criticizing Canada's historic connection with Britain. In 1958 another historian, Harry Crowe, was actually fired from Winnipeg's United College (forerunner of the University of Winnipeg) for unpublished comments about, among other things, the Conservative Party. He would, of course, later become dean of Atkinson here at York University.

From the 1960s onwards, there were nonetheless growing numbers of professors who engaged with a larger public on a wide range of issues. They reached out to audiences and forums beyond the narrow fraternity of their peers, to bring their knowledge and critical capacities to bear on a wide range of issues of public interest and concern. Their status as university professors gave them privileged access to public forums - politicians, newspaper editors, broadcasters, and others took them more seriously because of their academic credentials. That is not to say that they were always, or ever, popular figures in the public eye in this country, in the way that they often are in many European countries. Their status in the public arena has generally been much higher in Quebec than in English Canada, where anti-intellectualism still runs rampant. Remember that in 1995 the National Post held a competition to determine "the most important public intellectual in Canada," and the winner was Don Cherry.

I would like to suggest five broad categories of intellectual activities beyond the walls of academia. The first group I will call the Public Scholars. They have tried to carry the insights of their scholarly research outward, beyond the academic seminars, conferences, journals, and so on. They often wrote books completely within the conventions of their academic disciplines, that they nonetheless hoped would reach a wider educated readership and thus help to shape public thinking. To take one recent example, the health historian James Daschuk produced a book on indigenous health on the prairies in the context of nineteenth-century colonization, Clearing the Plains. ${ }^{2}$ This study got huge attention in the media, especially for its exposure of Prime Minister Sir John A. Macdonald's willingness to use hunger to force indigenous peoples onto reserves. That research has been taken up in many public discussions of indigenous rights in Canada. My own modest contribution 
has been a series of monographs and essay collections, which in all cases I hoped would make some impact beyond academia and perhaps contribute to broader struggles for social justice. I was probably most successful with a short history of the labour movement that actually found widespread use in union education programs as well as university classrooms.

Then there were the Popularizers. Many academics responded to requests to give lectures to general audiences on topics related to their expertise. Over the years I have responded to calls from dozens of groups, from historical societies to union conferences to public libraries to retirees' groups. I've also led numerous walking tours. Many professors took up invitations to appear in the media to similarly explain the insights of their scholarship to a popular audience. The Massey Lectures, the Canadian Broadcasting Company's (CBC) long-running Ideas series, and the weekly radio program Quirks and Quarks are leading examples of this kind of public exposure. Academics have also been encouraged to present their ideas in popular form through adult education, whether through university extension departments or independent organizations like the Workers' Educational Association.

As valuable as the outward flow of knowledge has been, I would argue that neither the Public Scholars nor the Popularizers have engaged with the public as much more than receptacles for their wisdom. The real public intellectual is one who tries to shape public awareness through more participatory processes. That gives us three more kinds of public intellectuals.

One is comprised of the Experts. A few academics have been asked to apply their expertise to specific social questions before courts or tribunals, perhaps on aboriginal claims, like my History colleague Bill Wicken, or on pay equity disputes, like my Sociology colleague Pat Armstrong. Sometimes they were asked to take on longer-term commitments. For more than a century in this country, some university-based intellectuals have responded to the siren call of the government commission, where they could sit with others from the non-academic world to shape public policy. Recent examples were historian Gérard Bouchard and philosopher Charles Taylor, who were co-chairs of Quebec's Consultation Commission on Accommodation Practices Related to Cultural Differences, which reported in 2008. Sometimes, that has led to longer-term recruitment into government bureaucracy or government institutions at some high level. Back in the 1930s and 1940s small armies of academics began to flow into the expanding federal civil service, and the flow has continued to the present. Some end up working for political parties. My late colleague Ramsay Cook published a book a few years ago about his speechwriting for Pierre Trudeau. And the political scientist Tom Flanagan has worked for a number of national Conservative leaders. A few, of course, might actually end up directly in politics. Pierre Trudeau was probably the most celebrated case, but we often forget that Ed Broadbent and Jack Layton also started out as university professors. John McCallum, Stéphane Dion, and Michael Ignatieff are some more recent Liberal examples. But in that environment, these people usually sacrifice their 
status as public intellectuals. The sanctity of intellectual independence evaporates, and the odour of opportunism hangs over them. In most cases, the track record of intellectuals in politics has not been impressive.

The Expert typically plays a role as fixer and problem-solver for the powers that be; as the agent of social engineering to smooth out social tensions. Maybe that is why I have seldom had calls to be one-who wants a Marxist-feminist labour historian to help construct public policy? But I would argue that the real public intellectuals in western countries are the ones who step outside the university to join more independent discussion and debate about large questions of public concern. Let us call them the Critics. They differ from the Experts in their tendency to express more critical judgments on the status quo and often to be more overtly political. They are more concerned with shaping public consciousness than with crafting detailed public policy. They enter circles of informed dialogue that can engage a considerable range of critical thinkers_-journalists, novelists, poets, artists, politicians, lawyers, architects, planners, and sundry other professionals, often derisively dubbed the "chattering classes." Their involvement may come in the form of a thoughtful article in a small journal or magazine, or an op-ed piece in a newspaper or, these days, a blog; or sometimes something more substantial in book form, distinct from the standard academic monograph. Recently, historian Ian McKay and his non-academic friend Jamie Swift have produced two excellent books that confront Canada's new culture of being a "warrior nation." 3 Occasionally a professor is drawn onto the editorial board of a magazine or journal. In French Canada Le Devoir epitomizes that kind of public intellectual forum. We have nothing quite so influential in English Canada, but some small publications have always tried to soldier on with the participation of academics, reaching small circles of concerned readers. Regrettably, none of these has ever had the size and impact of, say, the New York Review of Books or the Times Literary Supplement. The digital world is of course now creating space for many bloggers.

The mass media have had their own way of using such people-they like to turn them into pundits. Like many colleagues, I have been tapped a few times to play this role on TVOntario (TVO) and CBC, when they wanted to discuss issues from labour relations to drinking regulations. In these settings, academics often have less control over their expression of informed opinion than they have when they write an op-ed piece or a magazine column or a blog. The media may use such people to set up some kind of simplified debate, which may not reflect the subtler dialogue that academics themselves would take up. My least favourite memory of punditry is standing on my front lawn on the weekend of Labour Day about fifteen years ago, trying to convince a CBC interviewer that the Canadian labour movement was not dead in the water. In the end he extracted a ten-second clip that ignored my argument and upheld his pre-determined story line. Similar experiences with $\mathrm{CBC}$ have led me to refuse to do any more interviews for its flagship program, The National. In fact, the pool of pundits does not include all that many public intellec- 
tuals. Typically, the mainstream broadcasters rely on a small stable of commentators. Janice Gross Stein at the Munk School at the University of Toronto (U of T), for example, pops up regularly to discuss foreign affairs, as does Nelson Wiseman, also from $\mathrm{U}$ of $\mathrm{T}$, as a commentator on politics. Janice Stein is an exception since most media pundits are older white males, often located in central Canada, especially Toronto.

The final kind of public intellectual does more than express personal ideas and opinions. I will call these people the Committed. They agree to share their intellectual authority with others engaged in non-academic settings. That means a kind of collaboration with other groups, and the cultivation of respect for entirely different practices of work and decision-making than the ones in which academics have been trained. On the one hand, it can require working with artists, filmmakers, curators, and sundry professionals on projects in museums, galleries, archives, historic sites, theatres, and other cultural institutions, as well as work with independent broadcasters and filmmakers. I have worked at different points with the Ontario Museum Association, the Toronto District School Board, the Ontario Heritage Foundation, the City of Toronto Museums, and a few filmmakers.

On the other hand, some academics make a commitment to work with a variety of social movements or campaigns-Indigenous groups, women, labour, particular ethnic groups, and environmentalists, for example. The "public" they engage with is often quite different from the cultural snobs of the chattering classespartners that are often less well educated and not accustomed to working with people with PhDs. There is a long trail of such people stretching back decades in Canada.

I put a lot of energy into this kind of public intellectualism. For fifteen years, I sat on the board of the Workers' Arts and Heritage Centre (WAHC), located in Hamilton, alongside unionists, educators, artists, librarians, archivists, and more. I curated a few exhibitions at that centre and provided historical advice on several more. I also swept floors, set up chairs, tacked material to walls, served drinks, wrote research grants, and argued about historical interpretation. This was a challenging setting for an academic mostly accustomed to working alone and producing scholarly articles and books. I had to adapt to sharing my perspective with artists, designers, and curators, as well as labour partners. I also had to accommodate myself to working with three-dimensional modes of communication centred more on artifacts and spatial arrangements than on the printed word. One of my happiest moments was producing a table-top board game to convey the meaning of coping with poverty in the 1930s. I am now working with an equally diverse group under the banner of the Toronto Workers' History Project. All of this is what we now call Public History, and is at long last finding its way into university programs at York and several other universities across the country.

For quite some time those parts of the cultural sector in this country have needed our support in other ways. They have been under attack by neo-liberal gov- 
ernments that have little or no respect for the notion of the public in general. As president of the Canadian Historical Association I had to lead struggles to keep the services of Library and Archives Canada from being curtailed and to try to keep the University of Toronto from pushing the valuable United Church Archives off campus. Later I also rallied Toronto area historians to oppose the Toronto City Council's proposed closing of four museums, and helped to build a critique of the Harper government's move to transform the highly respected Canadian Museum of Civilization into the more politicized Canadian Museum of History.

So in all these ways university professors like me stepped out onto public stages and into public forums. Yet I think there is an additional dimension to being a public intellectual that is often ignored. We are not simply transmission belts outward from our offices and labs in the university; we also bring our external commitments and concerns into the university to challenge many of the conventions, practices, and priorities that have long dominated those institutions. We brought the public with us. We wanted to bring democracy to the university. Those outside experiences shaped what we thought should be taught and what research projects we felt drawn to take up, as well as how we thought the university should operate. We could call these the Outlaws.

I was something of an Outlaw. Half a century ago, I approached university life with a lot of awe and considerable scepticism. I think there were two reasons for that. The first was where I came from. I grew up in a working-class suburb on the eastern edge of Toronto in the semi-rural municipality known as Scarborough. My father was a blue-collar worker, and my mother was a secretary who also did most of the domestic labour for our family. In the neighbourhood where I grew up, I expect that nobody used the term "intellectual." I doubt that my family, kin, and neighbours would have known quite what one was, except perhaps as a stock character in comedy (Does anyone remember the stand-up comedian who called himself Professor Irwin Corey and styled himself “The World's Foremost Authority"? He just died in February 2017, at age 102). In the world of my childhood and youth, we were working people, and work with the hands was valued far above writing, speaking, and publishing. I was an oddity because I liked to read, did not much like sports, did not know how to take apart cars, and did well in school. But, as I reached university age in the mid 1960s, parents like mine were being encouraged to think about investing in the upward mobility of their children through more schooling. So my parents helped to propel their academically inclined son into university, the first in my family on either side.

At the University of Toronto in the late 1960s, I felt like an outsider. We now know that scarcely more than ten to twelve per cent of the burgeoning undergraduate student body in Ontario came from working-class families at that point. I spent my summers in high school and university working at blue-collar jobs- three summers in my uncle's metalworking sweatshop, three at Canadian Johns-Manville risking mesothelioma working with asbestos products. Meanwhile, many of my uni- 
versity classmates were travelling through Europe, sometimes for the second or third time. So I approached academia with a profound sense of difference-class difference.

Then, about 1968, I was shaken up by the radical politics that were percolating all around me on campus. Within a year I was elected to the student council, and was hanging out with elements of the New Left on campus and tapping into the channels of radicalism within the old Canadian Union of Students. Between 1969 and 1972, I participated in —and in two cases helped to lead—three occupations of university buildings over day care, library access, and student power in university decision-making. My mind was spinning through profound critiques of capitalism, imperialism, sexism, racism, consumerism, religion, and various forms of conformity, and was latching onto the importance of radical democracy encapsulated in our favourite slogan "Power to the People." Within the university we were critical of received wisdom about almost everything, and lashed out at academic authoritarianism, pomposity, and elitism.

That was the headspace in which I entered graduate school in 1971-a timid working-class kid with a head full of radical ideas about what was wrong with the world, and in particular what was wrong with the university. Somehow I eventually thought it would be possible to set out on an academic career with a different agenda — one that incorporated my ambivalence and scepticism about the academy as I had found it.

As a PhD student, I was particularly preoccupied with what to research and write about. Like other historians who had had a brush with the New Left, I wanted to focus on those who had been left out of mainstream historical scholarship—workers, women, immigrants, and Indigenous people in particular. For me, it was the working class that got the most attention. I got lots of support for my enthusiasm at the University of Warwick and Dalhousie University, where I did masters and doctoral work. By the time I defended my dissertation in 1981, social history was rapidly shaking up the old framework of conceptualizing the past, in Canada and elsewhere, and working-class history was starting to make an impact.

That first generation of labour historians was not merely telling a story that had been left out of traditional Canadian historical writing. We wanted to reconstruct the discipline with our new theories and empirical research. We were writing about structures of exploitation and oppression and about the complex histories of resistance by subordinate groups. We also reached outside the limited boundaries of the historical discipline for inspiration. We learned from political economists, anthropologists, the new scholars of gender and women's studies, and those who took us along the so-called linguistic turn. Interdisciplinary study and reading groups flourished (one of those I joined in 1981 is still running), as did interdisciplinary conferences. My immersion in these challenging, non-traditional forums and networks of discussion and debate was immensely stimulating and productive. We certainly helped to shake up a good deal of conventional thinking and intellectual 
practices within Canadian universities. Marxism, feminism, and anti-racism all eventually found space within the ivory tower in new tenured jobs, curricula, research centres, conferences, journals, and more.

Once I started a full-time teaching career at York in 1982, I had to think about how my politics would affect my teaching. For my first twenty-two years here, I was cross-appointed between the interdisciplinary Division of Social Science and the History Department, and was responsible for starting up a new Labour Studies Program. So I was regularly expected to address the contemporary relevance of my insights into labour history and industrial relations. I was conscious that many of my students had family backgrounds similar to mine, except that ever larger numbers of them also had immigration built into their family experiences. I also learned that most of them worked long hours to be able to attend university (much longer than my generation had), and therefore brought to the classroom lots of raw material for discussion. As a lecturer and in my reading assignments, I tried to challenge my students to rethink a lot of their received wisdom about the world of work and to reflect in new ways on their own work experience.

As a radical undergraduate in the 1960 s, I had prattled a lot about studentcentred learning, but in the 1980s, at a large university with huge classes, I had less pedagogical flexibility than I might have liked. I often put smaller classes through debates and role-playing, and for many years, following Bettina Bradbury's example, I had groups in one large class present dramatizations of some theme in Canadian working-class history every week at the front of the lecture hall (what I called "Workers' Heritage Moments"). I also designed assignments that regularly sent them outside the university to conduct interviews for their research projects- they generally loved doing that.

York was a newer university than that other hide-bound campus further south in the city, one that prided itself on its cutting-edge intellectual life. It did not take me long to realize that it was nonetheless weighed down by two negative forces. On the one hand, I found collegial life remarkably stuffy, conventional, elitist, and male-dominated; the treatment of the few women in the History Department was particularly disturbing. Gradually, over many years, the small number of us who were hired in the 1980s and 1990s_-many of them women — were able to establish an alternative kind of professionalism. It was possible to be serious and rigorous with casual attire, warm social relations, and compassion for our students and each other, rather than elitist pomposity and cold pretention.

Beyond the department, the other issue was the bewildering and frustrating university administration. By the time I arrived at York, Canadian universities were moving more determinedly towards a new kind of managerialism at the top, in response to rapid expansion and then severe financial restraints imposed by tightfisted provincial governments. Things, of course, got substantially and noticeably worse after 1995, when the Mike Harris Conservatives slashed university funding savagely. Student fees shot up, part-time academic work steadily increased, and our 
employment conditions stagnated or deteriorated. It became clear that strong unionism on campus was the only real hope to confront these pressures. Twice I walked picket lines for strikes launched by my faculty association. The nastier of these lasted for two months in 1997, and ended largely in defeat. More dramatic and in many ways more agonizing were the three CUPE strikes of teaching assistants, contract faculty, and graduate assistants between 2000 and 2015, which we full-time faculty had to support to varying degrees.

From the late 1990s onward, I became more and more conscious of what we now like to call governance issues. I served in the university Senate for twelve years over that period, and found myself in increasingly frequent battles. Essentially, like their counterparts across the country, the senior administration was attempting to curb collegial decision-making power by by-passing established decision-making bodies-especially faculty councils and the Senate. I butted heads with them over an attempt to bring onto campus a privately funded research centre, the Centre for International Governance Innovation (CIGI); over a ludicrous program prioritization project that threw the entire campus into crisis for months in 2013-2014; over an equally ludicrous and secretive decision to open a new campus in Markham; and so much more. In that process, many of us found the need to reassert democratic collegial governance among academic colleagues, as the positive, legitimate alternative to managerialism. Those battles are far from over.

So I was part of a generation of professors who thought it was important to rethink the relationship between the university and society, and the intellectual's role in that relationship. Do public intellectuals have a future in Canada (and further afield)? There have been growing danger signs and reasons to worry.

First, we have to acknowledge that intellectual life inside the academy has become intensely professionalized, specialized, and fragmented. Over the past halfcentury, intellectuals have been drawn away from public forums into more narrowly focused professionalized exchanges within proliferating sub-disciplines. We talk to ourselves in exclusive seminars, conferences, and academic journals, perhaps across disciplinary boundaries, but seldom in non-academic settings. The consequences have been disturbing. I share the concerns of such social critics as Russell Jacoby and Richard Posner that the modes of expression within academic circles have become increasingly arcane, often impenetrable by the uninitiated, and not balanced by any efforts to communicate those ideas in a more accessible fashion. ${ }^{4}$ What has been lost is the clarity of communication that was once prized, at least in the liberal arts. The public cannot know us if we do not know how to speak to them.

Yet I do not think the public intellectuals are in retreat simply because they have shot themselves in the foot. There are contextual problems that constrain or silence them. So, second, I would look to the state of the contemporary university as a threat to the pursuit of public intellectualism. The liberal arts, which have always supplied the largest numbers of publicly engaged academics, are under threat, as the utilitarian approach to higher education leaves them underfunded, under-pro- 
moted in university development strategies, and crippled by declining enrolments. Moreover, the pool of potential public intellectuals within the university is dwindling: the soaring numbers of contract faculty have far less time and independence to engage in the kinds of public engagement that full-time, tenure-stream faculty have enjoyed. Perhaps most disturbing is the growing emphasis by university administrators and provincial politicians on renegotiating the relationship between the academy and the broader society through a process of "accountability," a chorus that is reaching unbearable decibel levels. For several years, York has been calling itself the "engaged" university, a hugely ambiguous term. There is a real danger that our small initiatives in public outreach will be bracketed with much more ominous collaborations with corporate interests, exemplified at York by the CIGI incident. More than ever, we are being exhorted to make our teaching and research applied, quantifiable, and, where possible, commercially viable - an agonizing process for the liberal arts, whose very essence has always defied such formulations of our work. We need to continue to reassert our own versions of public engagement that retain the autonomy of our disciplinary practices and our academic institutions; that continue to allow for independent, ethically based criticism; and that are not caught up in any neo-liberal agendas. We cannot abandon the vital role of the university as a base of independent social criticism, made possible by the academic freedom that we honour and try to nurture.

Third, public intellectual life has undergone a substantial reorganization. The landscape of public policy debate is now littered with competing institutes and think tanks, each focused primarily on public policy issues and each with its own ideological axe to grind. To some extent this is laudable-I am particularly grateful to the well-publicized work of the Canadian Centre for Policy Alternatives. But the CCPA (and the newer Broadbent Institute) emerged as efforts to counter the expansive reach of well-established, well-funded right-wing think tanks, such as the Fraser Institute or the Manning Centre, which seek to dominate public discussion in diverse ways, including student recruitment on campus. What is most troubling about these new right-wing centres of public intellectualism is that they are driven by the neo-liberal values of the capitalist market (efficiency, productivity, flexibility, key performance indicators, and all the other buzz words), not by the broader, ethically driven values that motivated intellectual criticism for so many generations. They have already succeeded remarkably in rejigging the mainstream "common sense" in public discourse about the economy, the state, democracy and citizenship, the private and the social, and so much more — what is sometimes called "market fundamentalism."

Fourth, changing modes of communication have disrupted the established practices of public intellectualism. We have watched the media in which public intellectuals have been accustomed to engage wither and die, or become transformed into something quite disturbing. Bookstores are closing. Newspapers are shrinking, and serious journalism is in crisis — not least because many journalists, much like 
contract faculty, lack permanent employment and have little scope or independence to develop a critical, independent perspective. Small magazines have always had a difficult life in a country the size of Canada, but are now vanishing. The surviving media, largely in the hands of huge corporate oligopolies, tend to try to repackage news and analysis as entertainment. All too often, academics are simply tapped for their ten-second soundbites of narrowly focused expertise and given fewer opportunities for wide-ranging commentary.

That problem is compounded by emerging trends within social media. In the age of the Internet, not only is the public domain an increasingly fragmented space, but anyone who blogs can play at being an intellectual. There has certainly been a generally welcome democratization of knowledge production, but in this era of "post-truth" and "alternative facts," there is rampant confusion between disciplined knowledge-reasoned, evidence-based analysis—and simply passionate, ill-informed opinion. We are in danger of being drowned out by verbally nimble, cynical clowns.

Will anyone listen to us in the end? I think the answer to that question is open-ended. My own experience working with unionists has been sobering. I think we are generally respected, but not entirely trusted. They like to hear us as public intellectuals talking to the media with labour-positive messages, and they have seemed willing to tag along somewhat passively on the arts and heritage projects we set in motion. But, among many workers, there is a perfectly understandable discomfort with people coming out of the university environment. Unionists can sense a sharp class difference. Many years ago I was introduced to the chair of the Education Committee of the steelworkers' union local at Stelco in Hamilton, who bluntly said: "I know you professors-you either want to study us or change us," and walked away without shaking my hand. Labour historians are probably too earnest and too didactic for most working-class tastes. As we continue on through the Truth and Reconciliation process with Indigenous peoples in Canada, I worry that those kinds of tension will be in high relief.

So the interaction of the intellectual and the public has proved to be far more difficult than many of us imagined. The Public Scholar is finding a dwindling audience. The Popularizer gets pushed aside by the mass media. The Expert still gets some respect, but the Critic is in retreat. But I certainly don't want to end on a negative note. The most heartening trend is that the Committed are as busy as ever and finding new ways to communicate. To my mind, the most spectacular example has been the emergence of Active History, a website that publishes a historian's short essay on the contemporary relevance of his or her research almost every day and has an audience of thousands. It was developed over the past eight years entirely by talented, far-sighted graduate students in York University's History Department, and has become the voice of a new generation of historians in Canada (it has a francophone counterpart in Quebec). The site's statement of purpose is so encouraging: 
We define active history variously as history that listens and is responsive; history that will make a tangible difference in people's lives; history that makes an intervention and is transformative to both practitioners and communities. We seek a practice of history that emphasizes collegiality, builds community among active historians and other members of communities, and recognizes the public responsibilities of the historian. ${ }^{5}$

What better statement could there be of building the public into the intellectual. These new legions of younger colleagues are holding high the banner for a critical civic culture inside and outside the academy.

\section{NOTES}

${ }^{1}$ Versions of this paper were presented in May, 2017, to the Council of the Canadian Association of University Teachers and to a conference at York University. ${ }^{2}$ James Daschuk, Clearing the Plains: Disease, Politics of Starvation, and the Loss of Aboriginal Life (Regina: University of Regina Press, 2013).

${ }^{3}$ Ian McKay and Jamie Swift, Warrior Nation: Rebranding Canada in an Age of Anxiety (Toronto: Between the Lines, 2012); McKay and Swift, The Vimy Trap: Or, How We Learned to Stop Worrying and Love the Great War (Toronto: Between the Lines, 2016).

${ }^{4}$ Russell Jacoby, The Last Intellectuals: American Culture in the Age of Academe (New York: Basic Books, 1987); Richard A. Posner, Public Intellectuals: A Study in Decline (Cambridge, Mass.: Harvard University Press, 2001). 5 "About," Active History, http:/ / activehistory.ca/about/. 